\title{
Complicated and fatal Strongyloides infection in Canadians: risk factors, diagnosis and management
}

\begin{abstract}
StRONGYLOIDIASIS, WHICH IS CAUSED by the nematode Strongyloides stercoralis, is a common and persistent infection, particularly in developing countries. In the setting of compromised cellular immunity, it can result in fulminant dissemination with case-fatality rates of over $70 \%$. The majority of new Canadian immigrants come from countries where Strongyloides is highly endemic; therefore, the burden of Strongyloides may be underappreciated in Canada. Because early diagnosis and therapy can have a marked impact on disease outcome, screening for this infection should be considered mandatory for patients who have a history of travel or residence in a disease-endemic area and risk factors for disseminated disease (e.g., corticosteroid use and human Tlymphotropic virus type I infection).
\end{abstract}

Sue Lim, Kevin Katz, Sigmund Krajden, Milan Fuksa, Jay S. Keystone, Kevin C. Kain

CMAJ 2004;171(5):479-84

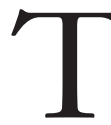

he following case is typical of a Strongyloides infection presenting to an infectious diseases service at a tertiary care hospital: A 50-year-old man who was originally from Cambodia but who had lived in Canada for the past 15 years presented with nausea and vomiting. His history was notable for arthritis, which was treated with prednisone, and type 2 diabetes mellitus. After admission, the patient became febrile and hypotensive. Blood cultures were positive for a gram-negative bacillus, and he was given ciprofloxacin and ceftriaxone. His respiratory status deteriorated, and Strongyloides larvae were incidentally noted on Gram stain and culture after bronchoalveolar lavage (Fig. 1). The patient was given $400 \mathrm{mg}$ of albendazole twice a day and $15 \mathrm{mg}$ of ivermectin once daily, but progressive respiratory failure followed and he died 3 weeks later.

This case exemplifies 2 key points. Foremost is that delays in establishing the diagnosis of strongyloidiasis can result in disseminated and fatal infection. Although the gastrointestinal tract is the primary site of Strongyloides infection, associated symptoms such as abdominal pain and intermittent diarrhea may be vague; if ignored by the clinician, the diagnosis may be made only upon dissemination and clinical deterioration of the patient. Second, eliciting an appropriate travel and migration history from patients and recognizing risk factors for disseminated infection are the essential epidemiologic clues for establishing early diagnosis. The purpose of this article is to highlight the risk factors and clinical presentation of strongyloidiasis and to provide a strategy for diagnosis and management. The goal is to raise awareness of this relatively common infection and thereby to facilitate early diagnosis and treatment of this potentially fatal but eminently curable disease.

\section{Epidemiology}

Strongyloides stercoralis is a common intestinal nematode that affects 30-100 million people worldwide; it is endemic in Africa, Asia, Southeast Asia, and Central and South America. ${ }^{1,2}$ Human infection occurs when infective (filariform) larvae penetrate intact skin. This most commonly happens when the host's bare feet come in direct contact with soil contaminated with infective Strongyloides larvae (Fig. 2). Once infected, most people have an asymptomatic, chronic infection of the gastrointestinal tract. However, because of the unique ability of $S$. stercoralis to complete its life cycle within the human host, the burden of worms can dramatically increase through a cycle of autoinfection. Autoinfection can lead to disease persistence as well as to hyperinfection syndrome, where the disease is disseminated amid impaired cellular immunity.

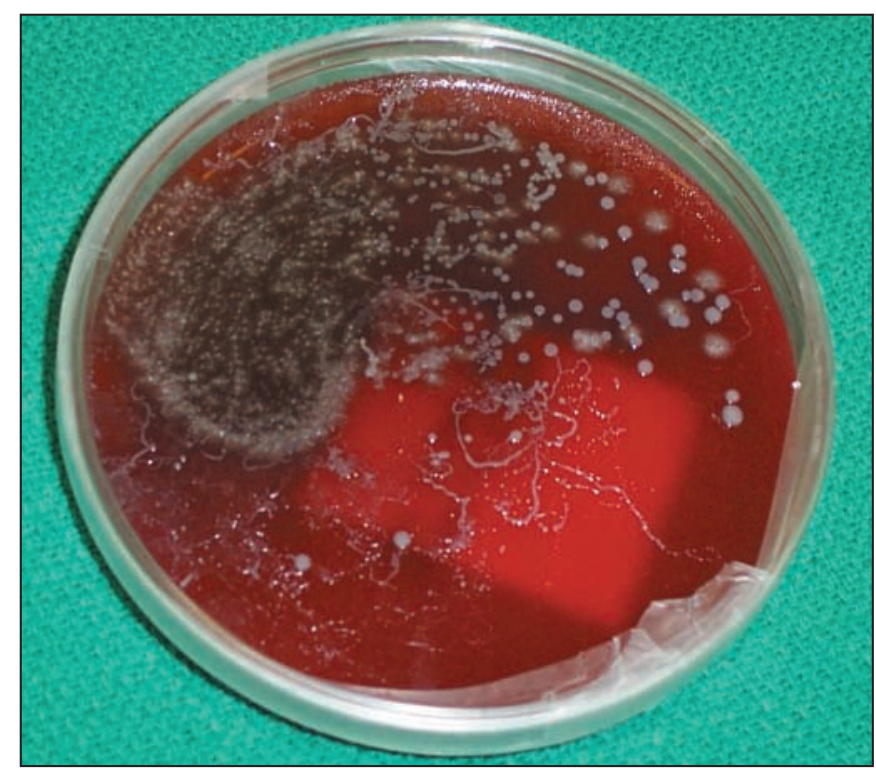

Fig. 1: Strongyloides stercoralis larva tracks on a blood agar plate from the bronchoalveolar lavage of a patient with disseminated strongyloidiasis. 
Although strongyloidiasis has traditionally been considered a tropical disease, increased worldwide travel and migration challenge this view. Canada's immigrant population, for example, has changed significantly over the past several decades. Before 1961, only 5.3\% of Canadian immigrants were from countries where Strongyloides infection is endemic. ${ }^{3}$ In contrast, 2001 Census data indicate that $77.5 \%$ of immigrants coming to Canada over the 10 -year

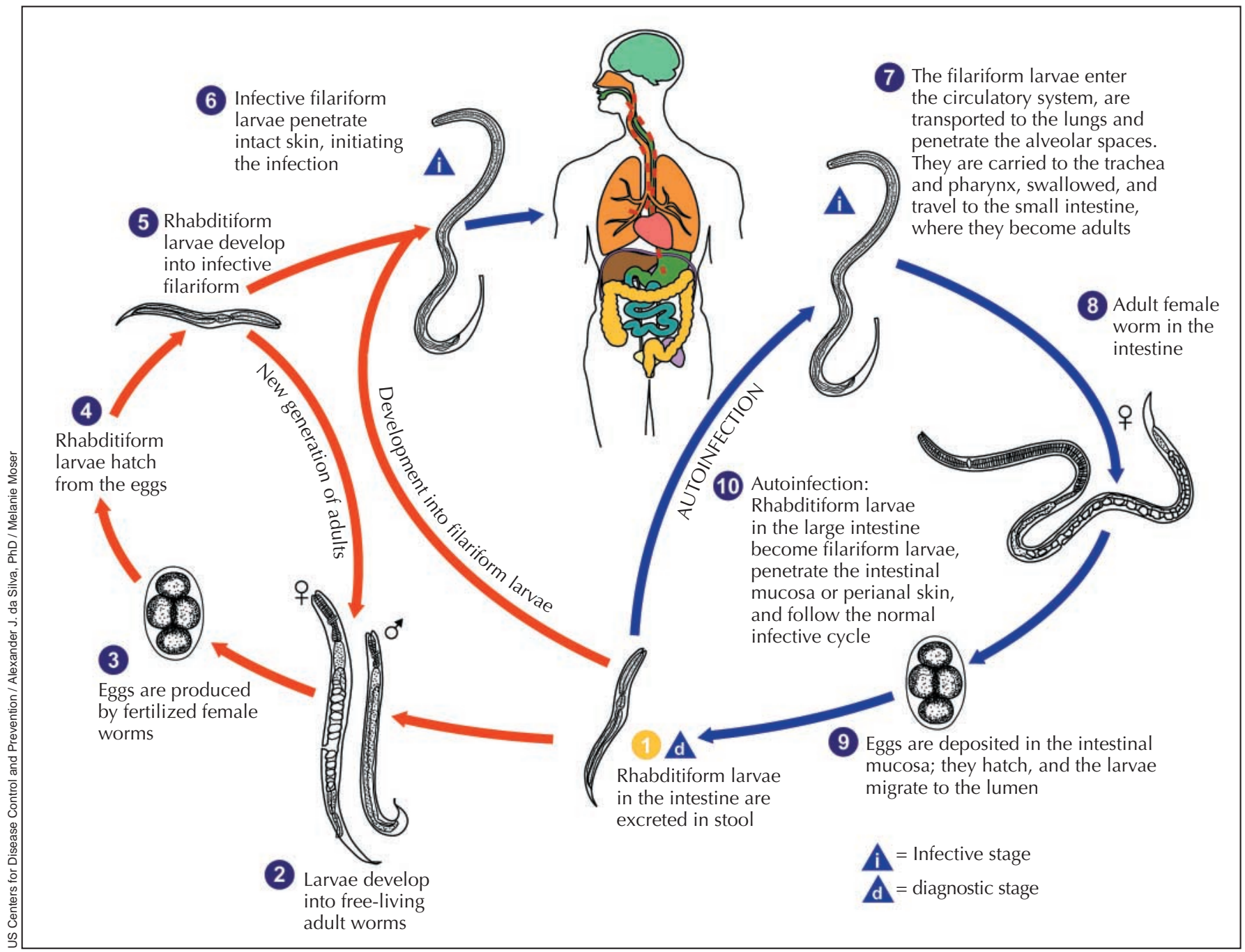

Fig. 2: The life cycle of Strongyloides stercoralis. The life cycle is more complex than that of most nematodes, with its alternation between free-living and parasitic cycles and its potential for autoinfection and multiplication within the host. In the free-living cycle, the rhabditiform larvae passed in the stool (1) can either moult twice and become infective filariform larvae (5) or moult 4 times and become free-living adult males or females (2) that mate and produce eggs (3), from which rhabditiform larvae hatch (4). The rhabditiform larvae (5) in turn can develop into either a new generation of free-living adults (2) or infective filariform larvae (6). The filariform larvae penetrate the human host skin to initiate the parasitic cycle (6). In the parasitic cycle, filariform larvae in contaminated soil penetrate the human skin (6) and are transported to the lungs, where they penetrate the alveolar spaces. They are carried through the bronchial tree to the pharynx, are swallowed and then reach the small intestine (7). In the small intestine they moult twice and become adult female worms (8). The females live threaded in the epithelium of the small intestine and, through parthenogenesis, produce eggs (9), which yield rhabditiform larvae. The rhabditiform larvae can either be passed in the stool (1) or cause autoinfection (10). In autoinfection, the rhabditiform larvae become infective filariform larvae, which can penetrate either the intestinal mucosa (internal autoinfection) or the skin of the perianal area (external autoinfection). In either case, the filariform larvae may follow the previously described route, being carried successively to the lungs, the bronchial tree, the pharynx and the small intestine, where they mature into adults, or they may disseminate widely in the body. To date, the occurrence of autoinfection in humans with helminthic infections is recognized only in S. stercoralis and Capillaria philippinensis infections. In the case of $S$. stercoralis, autoinfection may explain persistent infection in people who have not been in a disease-endemic area for many years and hyperinfection in immunodepressed patients. Source: Division of Parasitic Diseases, US Centers for Disease Control and Prevention, Atlanta. 
period between 1991 and 2001 were from Strongyloidesendemic countries. Furthermore, ethnic minorities born in Canada are also at increased risk for strongyloidiasis, since they are more likely to visit friends and relatives in diseaseendemic countries. Although the worldwide prevalence of Strongyloides is unknown, ${ }^{4}$ estimates are available from seroprevalence studies of high-risk populations. One study found that Southeast Asian refugees arriving in Canada had seroprevalence rates between $11.8 \%$ (Vietnamese) and $76.6 \%$ (Cambodians). ${ }^{5}$ According to Statistics Canada, $43.7 \%$ of Toronto's total population in 2001 was composed of foreign-born people, with the majority arriving from Strongyloides-endemic areas, including Southeast Asia, the Indian subcontinent and China. ${ }^{3}$ This suggests that strongyloidiasis may be an unrecognized infection among the Canadian population.

This contention is supported by observations of cases of disseminated strongyloidiasis in Canada. Over a 7-month period in 2002, a series of 10 consecutive cases of disseminated or fatal Strongyloides infection were identified in 2 academic hospitals in Toronto (see the online table at www.cmaj.ca/cgi/content/full/171/5/479/DC1). These cases highlight the epidemiology, risk factors, and diagnostic and management challenges associated with strongyloidiasis in areas where the disease is not endemic, such as Canada. Of these 10 cases, 7 were male, and the mean age was 64.6 (range 24-89) years. All of the patients were immigrants to Canada who acquired strongyloidiasis in their country of origin (3 in Asia, 6 in the Caribbean and 1 in Africa). One patient had lived in Canada for 56 years before symptoms developed. None acquired infection during travel to disease-endemic areas, although infection in Canadian travellers has been reported. ${ }^{6} \mathrm{With}$ respect to risk factors, corticosteroid use was documented in 4 of these 10 patients and positive human T-lymphotropic virus-1 (HTLV-1) serology was found in 3. Seven patients had disseminated infection with an associated mortality of $71 \%$.

\section{Clinical manifestations}

Table 1 outlines the common presenting symptoms based on the host's immune status. Gastrointestinal symptoms are the most common, and the respiratory tract is the system most frequently affected outside the gastrointestinal tract. Gram-negative or polymicrobial bacteremia ${ }^{7-10}$ from migration of larvae through the bowel wall is another common presentation of disseminated infection.

In the case of drug-induced or disease-associated defects in cellular immunity, autoinfection may lead to a massive increase in parasite burden and dissemination to almost all organ systems, including the lungs, liver and central nervous system. ${ }^{7,11}$ One study estimated that disseminated strongyloidiasis occurs in $1.5 \%-2.5 \%$ of infected patients. ${ }^{12}$ However, this number should be interpreted with caution, as the prevalence of Strongyloides infection is difficult to assess and is dependent upon geography, host immune status, test characteristics of available diagnostic assays and other factors. Nonetheless, it is generally agreed that disseminated strongyloidiasis has a high associated rate of death, with one review demonstrating a rate of $86 \% .^{13}$

\section{Risk factors for dissemination}

The association between impaired cellular immunity and a hyperinfective state was first reported in $1966 .{ }^{14-18}$ Risk factors for dissemination are shown in Box 1. Details of these mechanisms remain unclear, as there are have been cases of hyperinfection in people with no identifiable immunodeficiency. ${ }^{19-32}$

\begin{tabular}{|c|c|c|c|}
\hline Host & Common signs and symptoms & Eosinophilia & Treatment \\
\hline $\begin{array}{l}\text { Normal immune } \\
\text { system }\end{array}$ & $\begin{array}{l}\text { Gastrointestinal (most common): } \\
\text { progressive weight loss, diarrhea, } \\
\text { abdominal pain, vomiting } \\
\text { Dermatologic: larva currens (perianal, } \\
\text { rapidly moving and pruritic linear } \\
\text { eruption due to migration of larvae); this } \\
\text { symptom is pathognomonic of } \\
\text { strongyloidiasis }\end{array}$ & $\begin{array}{l}\text { Usually present } \\
\text { in }>70 \% \text { of cases }\end{array}$ & $\begin{array}{l}\text { Single drug: albendazole } 400 \mathrm{mg} \\
\text { twice daily } \times 7 \mathrm{~d} \text { OR ivermectin } \\
200 \mu \mathrm{g} / \mathrm{kg} \text { daily } \times 1-2 \mathrm{~d}\end{array}$ \\
\hline Immunosuppressed & $\begin{array}{l}\text { Same as host with normal immune } \\
\text { system } \\
\text { Respiratory (most common outside the } \\
\text { gastrointestinal tract): dyspnea, wheezing, } \\
\text { hemoptysis, cough, respiratory distress } \\
\text { Fever } \\
\text { Gram-negative/polymicrobial bacteremia } \\
\text { due to migration of larvae through the } \\
\text { bowel wall }\end{array}$ & Often absent & $\begin{array}{l}\text { Combination therapy: } \\
\text { albendazole } 400 \text { mg twice daily } \\
\times 7 \mathrm{~d} \text { AND ivermectin } 200 \mu \mathrm{g} / \mathrm{kg} \\
\text { daily } \times 1-2 \mathrm{~d} \\
\text { In cases of disseminated } \\
\text { strongyloidiasis, albendazole } \\
\text { and ivermectin are continued } \\
\text { until there is evidence that the } \\
\text { parasite is cleared }\end{array}$ \\
\hline
\end{tabular}


Corticosteroids, which target $\mathrm{T}$ cells, have been documented as an important factor in the subsequent development of hyperinfection. . $^{15,16,21,3,3,34}$

Hematologic cancers make up the majority of malignant diseases associated with hyperinfection, accounting for 20 of 22 malignant disease in one review. ${ }^{13}$ In general, malignant disease alone is rarely the sole factor for dissemination. ${ }^{13,35}$ The majority of patients who experience disseminated strongyloidiasis do so after they have received immunosuppressive therapy, usually prednisone, as treatment for their disease. Thus, although patients with hematologic cancer are known to have degrees of immune deficiency, ${ }^{36}$ the high frequency of corticosteroid use in this population confounds the strength of the association between disseminated strongyloidiasis and hematologic malignant disease.

Another major risk factor is HTLV-1 coinfection. HTLV-1 is a retrovirus associated with adult T-cell leukemia and HTLV-1-associated myelopathy, ${ }^{37}$ with adult T-cell leukemia developing in 3\%-5\% of HTLV-1 carriers after a long period of latency. ${ }^{38}$ This latent or preleukemic phase is reported to be up to 30 years shorter in HTLV-1 carriers who are coinfected with Strongyloides than in other HTLV-1-infected people. ${ }^{39-42}$ Monoclonal proliferation of the HTLV-1-infected cells has been shown to occur in coinfected patients but not in asymptomatic HTLV-1 carriers who do not have strongyloidiasis. ${ }^{43,44}$ Furthermore, the results of a recent study have shown that the Strongyloides antigen is implicated in T-cell proliferation and ultimately accelerates leukemogenesis. ${ }^{37}$ Successful treatment of strongyloidiasis may reverse clonal expansion by decreasing the HTLV-1 proviral load. ${ }^{38}$ This relationship appears to be bidirectional: not only does Strongyloides infection have an effect on the development of HTLV-1-associated malignant disease, but HTLV-1 inhibits cellular responses to Strongyloides infection. ${ }^{45-52}$

In a review of 27 cases in the West Indies, ${ }^{1}$ HTLV-1 infection was the most common condition (71\%) predisposing to dissemination. As well, 6 of the 7 patients who died were HTLV-1 positive, which suggests that coinfection is a marker of a poor prognosis. Given the significant correlation between HTLV-1 and strongyloidiasis in regions where the latter is endemic, such as the West Indies and Japan ${ }^{48}$ it has been suggested that each disease should prompt diagnostic efforts for the other. ${ }^{1}$

\section{Diagnosis and management}

A suggested diagnostic approach is shown in Table 2, which highlights the most likely clinical presentations encountered where one should suspect Strongyloides infection, followed by the appropriate diagnostic investigations.

Barriers to the prompt diagnosis of strongyloidiasis are multifaceted. First, since it is generally considered a "tropi-

Table 2: Diagnostic procedure for strongyloidiasis in people who have travelled to or lived in disease-endemic areas

\begin{tabular}{|c|c|}
\hline Presentation & Diagnostic procedure \\
\hline $\begin{array}{l}\text { Patient has gastrointestinal symptoms compatible } \\
\text { with uncomplicated strongyloidiasis (weight loss, diarrhea, } \\
\text { abdominal pain, vomiting) }\end{array}$ & $\begin{array}{l}3 \text { serial stool samples screened for ova and parasites } A N D \\
\text { enzyme-linked immunosorbent assay for } S \text {. stercoralis } \\
\text { serology }\end{array}$ \\
\hline \multicolumn{2}{|l|}{$O R$} \\
\hline \multicolumn{2}{|l|}{$\begin{array}{l}\text { Patient is asymptomatic but may be receiving corticosteroids } \\
\text { or other immunosuppressive therapy in the near future* }\end{array}$} \\
\hline $\begin{array}{l}\text { Patient is unwell and has pulmonary symptoms (wheezing, } \\
\text { respiratory distress), gram-negative } \\
\text { /polymicrobial sepsis and risk factors for disseminated } \\
\text { disease (see Box 1) }\end{array}$ & $\begin{array}{l}\text { Blood and sputum cultures for } S \text {. stercoralis, and culture } \\
\text { other specimens based on suspected organ involvement } \\
\text { (e.g., CSF) } \\
\text { AND }\end{array}$ \\
\hline & $\begin{array}{l}3 \text { serial stool samples screened for ova and parasites } A N D \\
\text { enzyme-linked immunosorbent assay for } S \text {. stercoralis } \\
\text { serology }\end{array}$ \\
\hline
\end{tabular}

Note: $\mathrm{CSF}=$ cerebrospinal fluid

*Strongyloidiasis should be recognized and treated before initiating immunosuppressive therapy, since once the disease disseminates it carries a high fatality rate regardless of therapeutic intervention. 
cal" disease, physicians may not be familiar with it, and appropriate investigations may be delayed. Second, the usual clinical presentation of gastrointestinal symptoms is nonspecific, and a wide range of clinical manifestations, from no symptoms to multi-organ failure, can occur decades after the primary infection. Furthermore, the sensitivity of stool examination for parasites is poor. Examination of a single stool sample may miss $70 \%$ or more of cases owing to low parasite burden and intermittent larval excretion., ${ }^{2,53,54}$ Diagnostic sensitivity increases to $50 \%$ with examination of 3 stool samples and is over $90 \%$ if 7 serial stool samples are examined. ${ }^{55,56}$ However, serologic testing with enzymelinked immunosorbent assay is both sensitive and specific, with estimates of $82 \%-95 \%$ sensitivity and $84 \%-92 \%$ specificity, and it can be an invaluable diagnostic tool. ${ }^{6.57-59}$ Third, eosinophilia, which is usually present in strongyloidiasis without hyperinfection, is often suppressed or absent in disseminated disease. ${ }^{17,34,60,61}$ Loutfy and colleagues found that $83 \%$ of patients with presumed strongyloidiasis had eosinophilia at the time of presentation. ${ }^{6}$ In fact, eosinopenia is now recognized as marking a poor prognosis. ${ }^{5}$

Two issues related to the management of strongyloides infection should be highlighted. First, the development of pulmonary symptoms and signs (e.g., acute respiratory distress syndrome, pulmonary infiltrates on chest radiograph, or both) in the setting of rapid clinical deterioration may represent Strongyloides hyperinfection. This should be recognized before the administration of corticosteroid therapy, which could have catastrophic effects in the setting of strongyloidiasis. In addition, because there are prognostic implications associated with HTLV-1 coinfection, it may be advisable to screen for this virus even after strongyloidiasis has been diagnosed. In practice, however, HTLV-1 screening is often performed only in cases of strongyloidiasis that are refractory to usual courses of therapy.

Treatment of strongyloidiasis depends on the patient's clinical status and underlying condition (Table 1). Test of cure with stool examination after therapy is insensitive, but monitoring a fall in Strongyloides antibody titres may be helpful. ${ }^{6,53,54,62}$

In conclusion, strongyloidiasis is a curable disease where early diagnosis and appropriate therapy can reduce associated mortality. ${ }^{1}$ Any person with a history of travel or residence in a disease-endemic area, even decades before presentation, should be investigated for strongyloidiasis (usually serologically) if that person presents with compatible symptoms or if he or she is asymptomatic but likely to receive corticosteroids or other immunosuppressive therapy in the near future.

This article has been peer reviewed.

From the Tropical Disease Unit, Division of Infectious Diseases, Department of Medicine (Lim, Keystone, Kain), University of Toronto, Toronto General Hospital-University Health Network (Lim, Katz, Keystone, Kain); the McLaughlinRotman Centre for Global Health, University of Toronto (Kain); and the Division of Infectious Diseases, St. Joseph's Health Centre (Krajden, Fuksa), Toronto, Ont.
Competing interests: None declared.

Contributors: All of the authors contributed to the design and reviewed and approved the final version of the manuscript. Sue Lim and Kevin Kain were primarily responsible for writing the manuscript.

\section{References}

1. Adedayo O, Grell G, Bellot P. Hyperinfective strongyloidiasis in the medical ward: review of 27 cases in 5 years. South Med 7 2002;95(7):711-6.

2. Siddiqui A, Berk S. Diagnosis of Strongyloides stercoralis infection. Clin Infect Dis 2001;33:1040-7.

3. Statistics Canada. 2001 Census nation tables. Ottawa: Statistics Canada;2002.

4. Genta RM. Global prevalence of strongyloidiasis: critical review with epidemiologic insights into the prevention of disseminated disease. Rev Infect Dis 1989;11:755-67.

5. Gyorkos TW, Genta RM, Viens P, MacLean JD. Seroepidemiology of Strongyloides infection in the Southeast Asian refugee population in Canada. Am 7 Epidemiol 1990;132:257-64.

6. Loutfy MR, Wilson M, Keystone JS, Kain KC. Serology and eosinophil count in the diagnosis and management of strongyloidiasis in a non-endemic area. Am 7 Trop Med Hyg 2002;66:749-52.

7. Longworth DL, Weller PF. Hyperinfection syndrome with strongyloidiasis. In: Remington JS, Swartz MN, editors. Current clinical topics in infectious diseases. New York: McGraw-Hill; 1986. p. 1.

8. Scowden EB, Schaffner W, Stone WJ. Overwhelming strongyloidiasis: an unappreciated opportunistic infection. Medicine 1978;57:527.

9. Strazzella WD, Safirstein BH. Asthma due to parasitic infestation. $N 7 \mathrm{Med}$ 1989;86:947-9.

10. Link L, Orenstein R. Bacterial complications of strongyloidiasis: streptococcus bovis meningitis. South Med 7 1999;92:728-31.

11. Woodring JH, Halfhill H, Reed JC. Pulmonary strongyloidiasis: clinical and imaging features. A7R Am 7 Roentgenol 1994;162:537-42.

12. Milder JE, Walzer PD, Kilgore G, Rutherford I, Klein M. Clinical features of Strongyloides stercoralis infection in an endemic area of the United States. Gastroenterology 1981;80;1481-8.

13. Igra-Siegman Y, Kapila R, Sen P, Kaminski ZC, Louria DB. Syndrome of hyperinfection with Strongyloides stercoralis. Rev Infect Dis 1981;3:397-407.

14. Rogers WA Jr, Nelson B. Strongyloidiasis and malignant lymphoma, "opportunistic infection" by a nematode. FAMA 1966;195:685-7.

15. Cruz R, Reboucas G, Rocha H. Fatal strongyloidiasis in patients receiving corticosteroids. NEngl 7 Med 1966;275:1093-6.

16. Willis AJP, Nwokolo C. Steroid therapy and strongyloidiasis. Lancet 1966;1: 1396-8.

17. Dwork KG, Jaffe JR, Lieberman HD. Strongyloidiasis with massive hyperinfection. N Y State 7 Med 1975;75:1230-4.

18. Purtilo DT, Meyers WM, Connor DH. Fatal strongyloidiasis in immunosuppressed patients. Am $\mathcal{F}$ Med 1974; 56:488-93

19. Cahill KM. Thiabendazole in massive strongyloidiasis. Am 7 Trop Med Hyg 1967;16:451-3

20. Amir-Ahmadi H, Braun P, Neva FA, Gottlieb LS, Zamcheck N. Strongyloidiasis at the Boston City Hospital. Emphasis on gastrointestinal pathophysiology and successful therapy with thiabendazole. Am 7 Dig Dis 1968;13:959-73.

21. Civantos F, Robinson MJ. Fatal strongyloidiasis following corticosteroid therapy. Am 7 Dig Dis 1969;14:643-51.

22. Walker-Smith JA, McMillan B, Middleton AW, Robertson S, Hopcroft A. Strongyloidiasis causing small-bowel obstruction in an aboriginal infant. Med F Aust 1969;2:1263-5.

23. Olurin EO. Strongyloidiasis causing fatal peritonitis. West Afr Med f 1970;19: 102-4.

24. Craven JL, Cantrell EG, Lewis MG. Strongyloides stercoralis infection presenting as necrotizing jejunitis [letter]. Trans R Soc Trop Med Hyg 1971;65:532-3.

25. Buss DH. Strongyloides stercoralis infection complicating granulocytic leukemia. NC Med 7 1971:32:269-74.

26. Adam M, Morgan O, Persaud C, Gibbs WN. Hyperinfection syndrome with Strongyloides stercoralis in malignant lymphoma. BM7 1973;1:264-6.

27. Rassiga AL, Lowry JL, Forman WB. Diffuse pulmonary infection due to Strongyloides stercoralis. 7AMA 1974;230:426-7.

28. Royle G, Fraser-Moodie A, Jones MW. Hyperinfection with Strongyloides stercoralis in Great Britain. Br 7 Surg 1974;61:498-500.

29. Pettersson T, Steinstrom R, Kyronseppa H. Disseminated lung opacities and cavitation associated with Strongyloides stercoralis and Schistosoma mansoni infection. Am F Trop Med Hyg 1974;23:158-62.

30. Kenney M, Webber CA. Diagnosis of strongyloidiasis in Papanicolaoustained sputum smears. Acta Cytol 1974;18:270-3.

31. Scoggin CH, Call NB. Acute respiratory failure due to disseminated strongyloidiasis in a renal transplant recipient. Ann Intern Med 1977;87:456-8.

32. Owor R, Wamukota WM. A fatal case of strongyloidiasis with strongyloides larvae in the meninges. Trans R Soc Trop Med Hyg 1976;70:497-9. 
33. Higenbottam TW, Heard BE. Opportunistic pulmonary strongyloidiasis complicating asthma treated with steroids. Thorax 1976;31:226-33.

34. Nagalotimath SJ, Ramaprasad AV, Chandrashekhar NK. Fatal strongyloidiasis in a patient receiving corticosteroids. Indian 7 Pathol Bacteriol 1974;17:190-2.

35. Genta RM, Miles P, Fields K. Opportunistic Strongyloides stercoralis infection in lymphoma patients. Report of a case and review of the literature. Cancer 1989;63:1407-11.

36. Harris JE. Immune deficiency states associated with human malignant disease. In: Harris JE, Sinkovics JG, editors. Immunology of malignant disease. 2nd ed. St. Louis: C.V. Mosby Co.; 1976. p. 283-369.

37. Satoh M, Toma H, Sugahara K, Etoh K, Shiroma Y, Kiyuna S, et al. Involvement of IL-2/IL-2R system activation by parasite antigen in polyclonal expansion of $\mathrm{CD}^{+} 25^{+} \mathrm{HTLV}$-1-infected T-cells in human carriers of both HTLV-1 and S. stercoralis. Oncogene 2002;21:2466-75.

38. Gabet A, Mortreux F, Talarmin A, Plumelle Y, Leclercq I, Leroy A, et al. High circulating proviral load with oligoclonal expansion of HTLV-1 bearing T cells in HTLV-1 carriers with strongyloidiasis. Oncogene 2000;19:4954-60.

39. Cleghorn FR, Manns A, Falk R, Hartge P, Hanchard B, Jack N, et al. Effect of human T-lymphotropic virus type I infection on non-Hodgkin's lymphoma incidence. 7 Natl Cancer Inst 1995;87:1009-14.

40. Plumelle Y, Gonin C, Edouard A, Bucher BJ, Thomas L, Brebion A, et al. Effect of Strongyloides stercoralis infection and eosinophilia on age at onset and prognosis of adult T-cell leukemia. Am 7 Clin Pathol 1997;107:81-7.

41. Pombo de Oliverira MS, Matutes E, Schulz T, Carvalho SM, Noronha H, Reaves JD, et al. T-cell malignancies in Brazil. Clinico-pathological and molecular studies of HTLV-I-positive and -negative cases. Int 7 Cancer 1995;60: 823-7.

42. Yamaguchi K, Matutes E, Catovsky D, Galton DA, Nakada K, Takatsuki K. Strongyloides stercoralis as candidate co-factor for HTLV-I-induced leukaemogenesis. Lancet 1987;2:94-5.

43. Nakada K, Yamaguchi K, Furugen S, Nakasone T, Nakasone K, Oshiro Y, et al. Monoclonal integration of HTLV-I proviral DNA in patients with strongyloidiasis. Int 7 Cancer 1987;40:145-8.

44. Yoshida M, Osame M, Kawai H, Toita M, Kuwasaki N, Nishida Y, et al. Increased replication of HTLV-I in HTLV-I-associated myelopathy. Ann Neurol 1989;26:331-5

45. Gotuzzo E, Terashima A, Alvaraz H, Tello R, Infante R, Watts DM, et al. Strongyloides stercoralis hyperinfection associated with human T-cell lymphotropic virus type-1 infection in Peru. Am 7 Trop Med Hyg 1999;60:146-9.

46. Neisson-Vernant C, Eduoard A. Malignant strongyloidiasis and the HTLV-1 virus [in French]. Rev Prat 1990;40:2127-8.

47. Newton RC, Limpuamgthip P, Greenberg S, Gam A, Neva FA. Strongyloides stercoralis hyperinfection in a carrier of $\mathrm{HTLV}-1$ virus with evidence of selective immunosuppression. Am $\mathcal{7}$ Med 1992;92:202-8

48. Hayashi J, Kishihara Y, Yoshimura E, Furusyo N, Yamaji K, Kawakami Y, et al. Correlation between human T-cell lymphotropic virus type-1 and Strongyloides stercoralis infections and serum immunoglobulin $\mathrm{E}$ responses in residents of Okinawa, Japan. Am 7 Trop Med Hyg 1997;56:71-5.

49. McRury J, Messias IT, Walzer PD, Huitger T, Genta RM. Specific IgE responses in human strongyloidiasis. F Clin Exp Immunol 1986;65:631-8.

50. Genta RM, Douce RW, Walzer PD. Diagnostic implications of parasitespecific immune responses in immunocompromised patients with strongyloidiasis. 7 Clin Microbiol 1986;23:1099-103.

51. Plumelle Y, Pascaline N, Nguyen D, Panelatti G, Jouannelle A, Jouault H, et al. Adult T-cell leukemia-lymphoma: a clinico-pathologic study of twenty-six patients from Martinique. Hematol Pathol 1993;7:251-62.

52. Robinson RD, Lindo JF, Neva FA, Gam AA, Vogel P, Terry SI, et al. Immunoepidemiologic studies of Strongyloides stercoralis and human T lymphotropic virus type I infections in Jamaica. 7 Infect Dis 1994;169:692-6.

53. Liu LX, Weller PF. Strongyloidiasis and other intestinal nematode infections. Infect Dis Clin North Am 1993;7:655-82.

54. Uparanukraw P, Phongsri S, Morakote N. Fluctuations of larval excretion in Strongyloides stercoralis infection. Am 7 Trop Med Hyg 1999;60:967-73.

55. Nielson PB, Mojon M. Improved diagnosis of strongyloides stercoralis by seven consecutive stool specimens. Zentralbl Bakteriol Mikrobiol Hyg [A] 1987;263: $616-8$
56. Pelletier LL. Chronic strongyloidiasis in World War II Far East ex-prisoners of war. Am 7 Trop Med Hyg 1984;33:5 5-61.

57. Carroll SM, Karthigasu KT, Grove DI. Serodiagnosis of human strongyloidiasis by an enzyme-linked immunosorbent assay. Trans $R$ Soc Trop Med Hyg 1981;75:706-9.

58. Neva FA, Gam AA, Burke J. Comparison of larval antigens in an enzymelinked immunosorbent assay for strongyloidiasis in humans. 7 Infect Dis 1981 144:427-32.

59. Savage D, Foadi M, Haworth C, Grant A. Marked eosinophilia in an immunosuppressed patient with strongyloidiasis. 7 Intern Med 1994;236:473-5.

60. Aziz EM. Strongyloides stercoralis infestation: review of the literature and report of 33 cases. South Med 7 1969;62:806-10.

61. Huchton P, Horn R. Strongyloidiasis. 7 Pediatr 1959;55:602-8

62. Kobayashi J, Sato Y, Toma H, Takara M, Shiroma Y. Application of enzyme immunoassay for postchemotherapy evaluation of human strongyloidiasis. $\mathrm{Di}$ agn Microbiol Infect Dis 1994;18:19-23.

Correspondence to: Dr. Kevin C. Kain, Tropical Disease Unit, ES 9-412, Toronto General Hospital, 200 Elizabeth St., Toronto ON M5G 2C4

2004 W ORKSHOP SCHEDULE
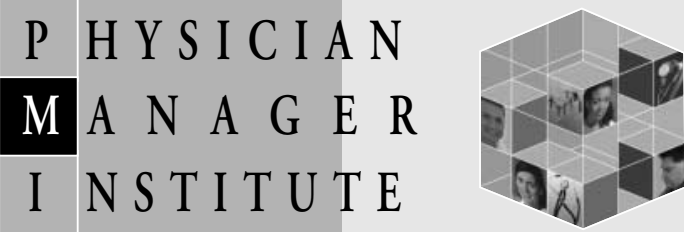

A five level credit program exclusively for physicians designed to develop superior leadership and management skills

Approved for RCPSC, CFPC, CCHSE credits

PMI I/II

Sept. 26-28 / Sept. 29-0ct. 1

Calgary, AB

PMI III/IV

Nov. 7-9 / Nov. 10-12

Vancouver, BC

PMI Refresher

Oct. 22-24

Vancouver, BC

In-house PM I

A practical, cost effective and focused training opportunity held on-site for medical leaders and managers

FOR INFORMATION:

tel $800663-7336$ or $613731-8610$

X2319 (PMI) or X2261 (In-house PMI)

professional_development@cma.ca

che.ce 